\title{
Effect of Gambisan on the Inhibition of Adipogenesis in 3T3-L1 Adipocytes
}

\author{
Jung Won Kang,, Dongwoo Nam, ${ }^{1}$ Kun Hyung Kim, ${ }^{1}$ Jeong-Eun Huh, ${ }^{2}$ and Jae-Dong Lee ${ }^{1}$ \\ ${ }^{1}$ Department of Acupuncture and Moxibustion, College of Korean Medicine, Kyung Hee University, 1 Hoegi-dong, Dongdaemun-gu, \\ Seoul 130-702, Republic of Korea \\ ${ }^{2}$ Oriental Medicine Research Center for Bone and Joint Disease, East-West Bone and Joint Research Institute, Kyung Hee University, \\ 149 Sangil-dong, Gangdong-gu, Seoul 134-727, Republic of Korea
}

Correspondence should be addressed to Jeong-Eun Huh; jehuh2551@hanmail.net and Jae-Dong Lee; ljdacu@gmail.com

Received 26 March 2013; Revised 10 June 2013; Accepted 12 June 2013

Academic Editor: Hyunsu Bae

Copyright (C) 2013 Jung Won Kang et al. This is an open access article distributed under the Creative Commons Attribution License, which permits unrestricted use, distribution, and reproduction in any medium, provided the original work is properly cited.

\begin{abstract}
This study was conducted to explore the antiadipogenic effect and possible mechanism of Gambisan on 3T3-L1 cells. For quality control, Gambisan was standardized by HPLC and the standard compounds ephedrine, epigallocatechin-3-gallate, and caffeine were screened. Cultured 3T3-L1 cells that had been induced to differentiate were treated with various concentrations of Gambisan or its major component extracts (Ephedra intermedia Schrenk, Atractylodes lancea DC., and Thea sinensis L.) for 72 hours for MTT assay to determine cell viability or 10 days for LDH assay, triglyceride assay, DNA content measurement, Oil red O staining, RT-PCR, and western blot. Gambisan significantly inhibited adipogenesis in 3T3-L1 cells by reducing triglyceride contents and lipid accumulation in a dose-dependent manner without obvious cytotoxicity. Viability and DNA content in 3T3-L1 cells treated with Gambisan were significantly higher than cells treated with the major component extracts at every concentration. The anti-adipogenic effects of Gambisan appeared to be mediated by a significant downregulation of the expression of lipoprotein lipase mRNA and PPAR $\gamma$, $\mathrm{C} / \mathrm{EBP} \alpha$, and SREBP-1 protein apart from the expression of hormone-sensitive lipase. Gambisan could act as a possible therapeutic agent for obesity. However, further studies including in vivo assays and clinical trials are needed to confirm the efficacy, safety and mechanisms of the antiobesity effects of Gambisan.
\end{abstract}

\section{Introduction}

Obesity, defined as an excessive body weight in the shape of fat accumulation that may impair health, is one of the most common global metabolic disorders, affecting up to an estimated $61 \%$ of adults including both overweight and obese. In particular, it has been conclusively linked with various medical conditions including dyslipidemia, diabetes mellitus, hypertension, some cancers, and osteoarthritis (OA) [1,2].

These relationships rely on the excessive differentiation and growth of adipocytes, the main constituent of fat, which leads to increased fat cell mass and number, adipogenesis including structural changes, lipid accumulation and lipogenic enzyme expression, and surplus energy accumulation stored as triglyceride (TG) in adipocytes [3-5]. Consequently, inhibition of the adipogenesis and TG deposition in 3T3-L1 adipocytes could be of crucial therapeutic importance in compounds developed to treat and even prevent obesity.
The primary treatments of obesity are lifestyle modification, drug therapy, and bariatric surgery. The most basic and effective means of achieving productive lifestyle changes are a combination of behavioral therapies, dietary modification and regular exercise $[6,7]$. However, pharmacotherapy is recommended when these kinds of approaches prove insufficient or when obesity is severe.

Although some weight loss medications have been licensed and marketed in the past several, most including sibutramine, amphetamines, and rimonabant have been withdrawn because of serious adverse events including cardiovascular problems $[8,9]$. There is a pressing need for developing antiobesity drugs that are efficacious and have minimal side effects.

In this sense, there have been many studies exploring the effects and potential mechanism of candidate remedies from single medicinal herbs [10-12] or complex herbal 
prescriptions [13-16] because of their comparative safety and evidence identified by accumulated clinical experiences over hundreds of years in Asian countries including Korea.

Gambisan, designated as HH911G in Kyung Hee University Korean Medicine Hospital (Seoul, Korea), is a novel antiobesity herbal extract formula composed of four medicinal herbs. It was formulated by modifying Wolbigachultang recorded in the traditional medical classic literature Jinguiyaolue and adding Thea sinensis L. to reinforce the weightloss effect and to lessen the well-known side effects of its component herbs or standard compounds [17-22] through scholarly consensus among the faculty of College of Korean Medicine, Kyung Hee University. Despite the widespread clinical use of Gambisan, involving over 2,800,000 doses for the past 3 years, the mechanism of its therapeutic effect has not yet been elucidated.

In the present study, the anti-obesity effect of Gambisan and its mechanism of action were investigated in differentiating mouse 3T3-L1 adipocytes [23], a basic and robust model to assess adipogenesis and adipocyte metabolism in vitro, by measuring viability, TG deposition, lipid droplet accumulation in the treated cells, and expression levels of several adipocyte-specific genes [24] including hormonesensitive lipase (HSL) and lipoprotein lipase (LPL) and major adipogenic transcriptional factors [25] including peroxisome proliferator-activated receptor gamma (PPAR $\gamma)$, CCAAT/enhancer binding protein alpha $(\mathrm{C} / \mathrm{EBP} \alpha)$, and sterol regulatory element binding protein-1 (SREBP-1).

\section{Material and Methods}

2.1. Materials. 3-(4,5-Dimethylthiazol-2-yl)-2,5-diphenyltet-razolium bromide (MTT), Oil red O solution, 3-isobutyl1-methylxanthine (IBMX), dimethyl sulfoxide (DMSO), dexamethasone (DEX), insulin (INS), isopropanol, formalin, and ethylenediaminetetraacetic acid (EDTA) were obtained from Sigma-Aldrich (St. Louis, MO, USA). Dulbecco's modified Eagle's medium (DMEM), fetal bovine serum (FBS), phosphate buffered saline (PBS), penicillin, streptomycin, and new bone calf serum (NBCS) were purchased from Gibco BRL (Grand Island, NY, USA).

Trizol reagent was bought from Invitrogen (Carlsbad, $\mathrm{CA}, \mathrm{USA}$ ). Mouse monoclonal antibodies against $\operatorname{PPAR} \gamma$, $\mathrm{C} / \mathrm{EBP} \alpha$, and SREBP-1 were from Cell Signaling Technology (Beverly, MA, USA), and $\beta$-actin antibody was from SigmaAldrich. An reverse transcription-polymerase chain reaction (RT-PCR) kit and primers were provided by TaKaRa Biotechnology (Seoul, Korea). Horseradish peroxidase (HRP)conjugated anti-mouse IgG antibody, cold lysis buffer, and 4$12 \%$ sodium dodecyl sulfate-polyacrylamide electrophoresis (SDS-PAGE) gels were acquired from Invitrogen.

All other reagents, unless noted, were purchased from Sigma-Aldrich.

2.2. Preparation of Gambisan and Its Major Component Extracts. Gambisan is routinely mass produced in the Department of Pharmacy, Kyung Hee University Korean Medicine Hospital. Gambisan and its major component extracts (Ephedra intermedia Schrenk, Atractylodes lancea DC., and Thea sinensis L.) were obtained from Kyung Hee University Korean Medicine Hospital. They were identified by Dr. Nam-Jae Kim, director of the Department of Pharmacy, Kyung Hee University Korean Medicine Hospital. Voucher specimens were preserved at the Oriental Medicine Research Center for Bone and Joint Disease, Kyung Hee University. The constituents of Gambisan were Ephedra intermedia Schrenk (12 g), Gypsum Fibrosum (16 g), Atractylodes lancea DC. (8 g), and Thea sinensis L. (20 g).

To prepare Gambisan, a ground mixture of Ephedra intermedia Schrenk, Gypsum Fibrosum, and Atractylodes lancea DC. was extracted twice at a respective ratio of $3: 4: 2(\mathrm{w} / \mathrm{w})$ with boiling distilled water for $2 \mathrm{hr}$ in a reflux apparatus. The aqueous extracted solution was filtered and evaporated using a rotary evaporator (EYELA, Tokyo, Japan) in vacuo and lyophilized in a freeze dryer (EYELA) to completely remove residual solvent to produce a brown powder in a yield of about $19.44 \%$ compared with raw herbal materials. Thea sinensis L. alone was extracted separately as just described and Gambisan was finally manufactured by mixing the extracted mixture and Thea sinensis L. powdered extract at a ratio of $1: 0.8$

The major components of Gambisan were also extracted twice with boiling distilled water for $2 \mathrm{hr}$ by reflux apparatus. The aqueous extraction was filtered and evaporated in vacuo and lyophilized in a freeze dryer to ensure complete removal of water yielding about $18.9 \%, 21.8 \%$, and $31.5 \%$ of brown powder containing Ephedra intermedia Schrenk, Atractylodes lancea DC., and Thea sinensis L., respectively.

2.3. High Performance Liquid Chromatography (HPLC) Analysis of Gambisan and Its Standard Compounds. Gambisan was standardized for quality control by HPLC analysis and the reference standard compounds (ephedrine, EGCG, and caffeine) were identified. Chromatographic analysis of Gambisan and its standard compounds was performed with a reverse-phase HPLC system (Waters, Milford, MA, USA) equipped with the Waters Breeze System (Alliance 2695 separation module and 2996 photodiode array detector (PDA)). Separation was carried out using a Hydrosphere $\mathrm{C}_{18}$ column $(4.6 \times 250 \mathrm{~mm}$, particle diameter $5 \mu \mathrm{m}$; YMC, Kyoto, Japan $)$ at $30-45^{\circ} \mathrm{C}$. The mobile phase of ephedrine, EGCG, and caffeine consisted of $0.1 \%$ phosphoric acid solution in sodium lauryl sulfate (SLS) : acetonitrile (can): $\mathrm{H}_{3} \mathrm{PO}_{4}=640: 360: 1,20 \%$ tetrahydrofuran (THF), and SLS : ACN : $\mathrm{H}_{3} \mathrm{PO}_{4}=900: 100: 1$, respectively. Detection of ephedrine, caffeine, and EGCG was performed at $210 \mathrm{~nm}, 280 \mathrm{~nm}$, and $280 \mathrm{~nm}$, respectively (Figure 1).

2.4. Cell Culture, Differentiation, and Treatment. The 3T3-L1 mouse embryo fibroblasts were obtained from the American Type Culture Collection (ATCC CL-173; Manassas, VA, USA). Cells were cultured in high glucose DMEM supplemented with $10 \% \mathrm{NBCS}, 100 \mathrm{U} / \mathrm{mL}$ penicillin, and $0.1 \mu \mathrm{g} / \mathrm{mL}$ streptomycin to $90 \%$ confluence. The cells were induced to differentiate with differentiation medium (DMEM containing $5 \% \mathrm{FBS}, 1 \mu \mathrm{M}$ DEX, $1 \mu \mathrm{g} / \mathrm{mL}$ INS, and $0.5 \mathrm{mM}$ IBMX). 


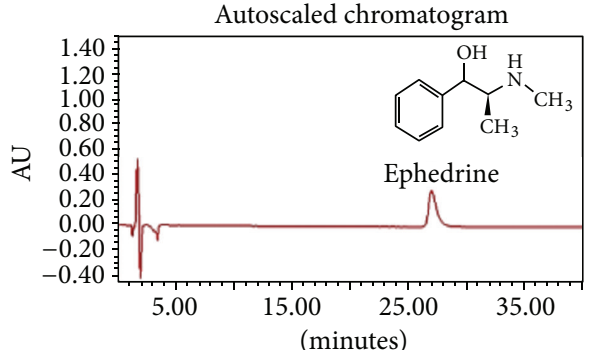

(a) Ephedrine

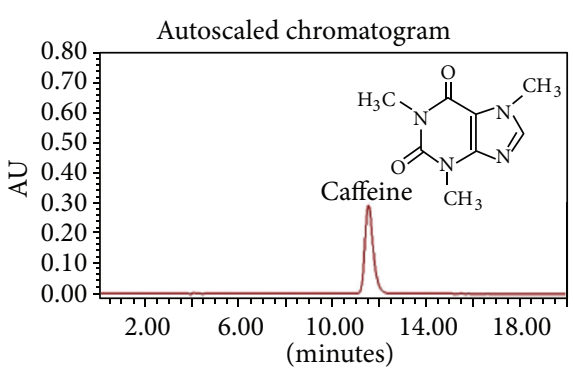

(c) Caffeine

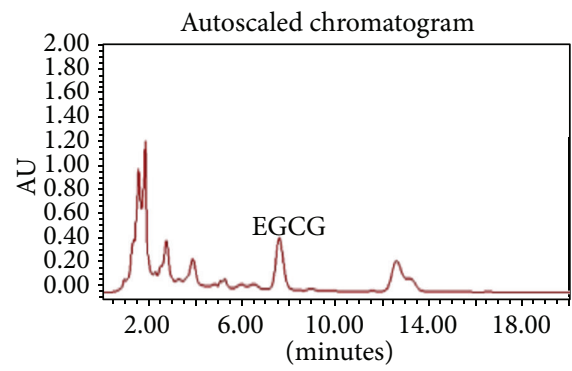

(e) EGCG in Gambisan

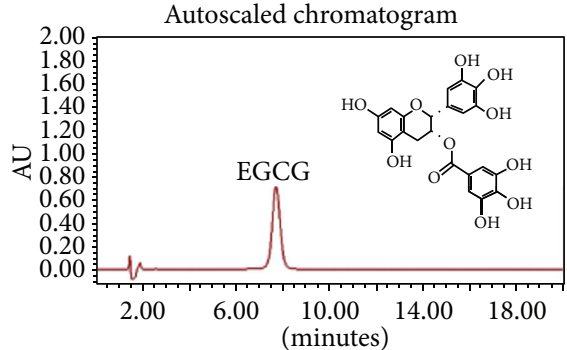

(b) EGCG

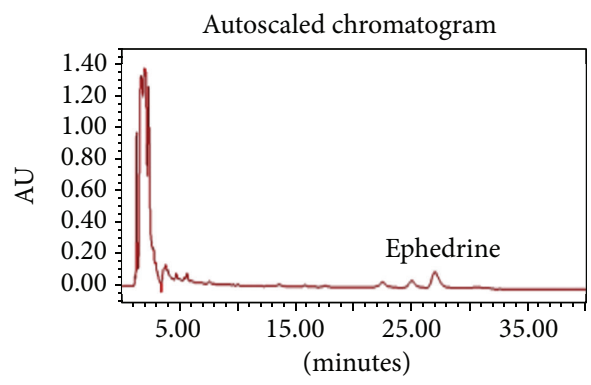

(d) Ephedrine in Gambisan

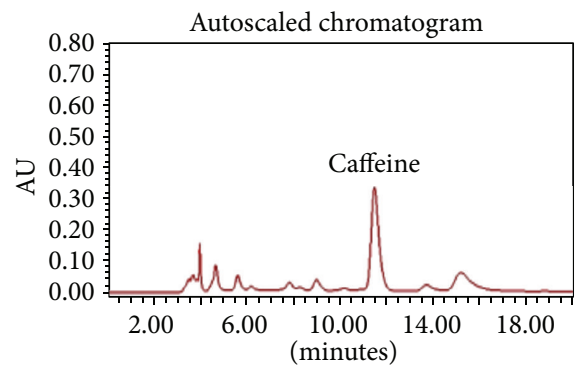

(f) Caffeine in Gambisan

FIGURE 1: HPLC profiles of Gambisan and its standard compounds of ephedrine, EGCG, and caffeine. (a), (b), and (c) are profiles of standard ephedrine, EGCG, and caffeine, respectively. (d), (e), and (f) are profiles of ephedrine, EGCG, and caffeine extracted from Gambisan. Detection was done at $210 \mathrm{~nm}$ (about $27 \mathrm{~min}$ ), $280 \mathrm{~nm}$ (about $7.5 \mathrm{~min}$ ), and $280 \mathrm{~nm}$ (about $11.5 \mathrm{~min}$ ), respectively.

Beginning 2 days later, the medium was replenished with fresh differentiation medium every other day and maintained at $37^{\circ} \mathrm{C}$ in a humidified $5 \% \mathrm{CO}_{2}$ atmosphere throughout the experiments until the cells were harvested. The differentiated 3T3-L1 cells were treated with various concentrations of Gambisan or its major component extracts. Cell viability after $72 \mathrm{hr}$ was measured by MTT assay, and the cultured cells were used for the further analyses after 10 days.

\subsection{Cell Viability Assay}

2.5.1. MTT Assay. The 3T3-L1 preadipocytes were seeded at a density of $1 \times 10^{4}$ cells per well in 96-well plates and incubated in culture medium. The cells were then treated with various doses $(0.01-1000 \mu \mathrm{g} / \mathrm{mL})$ of Gambisan or its major component extracts. After $72 \mathrm{hr}$, the cells were incubated in the dark with an MTT solution for $4 \mathrm{hr}$ at $37^{\circ} \mathrm{C}$. The supernatants were aspirated, DMSO was added to each well, and the plates were agitated to dissolve the formazan crystal product. Absorbance was then measured at $570 \mathrm{~nm}$ using a multiwell plate reader (Molecular Devices, Sunnyvale, CA, USA). The percentage of viable cells was calculated by defining the cell viability without treatment as $100 \%$.

2.5.2. LDH Assay. The 3T3-L1 preadipocytes were seeded at a density of $2 \times 10^{4}$ cells per well in 24 -well plates and cultured $90 \%$ confluence in culture medium. The cells were then treated with various concentrations $(0.01-1000 \mu \mathrm{g} / \mathrm{mL})$ of Gambisan or its major component extracts for 10 days. As an indicator of cytotoxicity, the cytoplasmic enzyme lactate dehydrogenase (LDH) was measured in the culture supernatant of the Gambisan or its major component extractstreated differentiating 3T3-L1 cells. An optimized LDH test (Promega, Madison, WI, USA) was used to quantify LDH activity in the medium of the treated differentiating 3T3-L1 cells. The percentage of viable cells was calculated by defining the cell viability without treatment as $100 \%$.

2.6. TG Assay and DNA Contents Measurement. The cellular contents of TG were determined using a TG determination 
TABLE 1: Gene-specific forward and reverse primer sequences used for RT-PCR analysis.

\begin{tabular}{lccc}
\hline Target gene names & Direction & Primer sequence & Annealing time (cycles) \\
\hline \multirow{2}{*}{ HSL } & Forward & $5^{\prime}$-GAGGGACACACACACACCTG-3 & $55^{\circ} \mathrm{C}(30)$ \\
\hline \multirow{2}{*}{ LPL } & Reverse & $5^{\prime}$-CCCTTTCGCAGCAACTTTAG-3 & \\
& Forward & $5^{\prime}$-AGTAGACTGGTTGTATCGGG-3 & $55^{\circ} \mathrm{C}(30)$ \\
\hline \multirow{2}{*}{$\beta$-actin } & Reverse & $5^{\prime}$-AGCGTCATCAGGAGAAAGG-3 & $55^{\circ} \mathrm{C}(32)$ \\
& Forward & $5^{\prime}$-AGCCATGTACGTAGCCATCC-3 & \\
\hline
\end{tabular}

HSL: hormone-sensitive lipase, LPL: lipoprotein lipase, RT-PCR: reverse transcription-polymerase chain reaction.

kit (Wako, Osaka, Japan) according to the manufacturer's instructions. Briefly, the cells were rinsed three times with PBS and scrapped off the plate with rubber policeman. The cells were extracted with $1 \mathrm{~mL}$ of lysis buffer $(50 \mathrm{mM}$ Tris, $0.15 \mathrm{M} \mathrm{NaCl}, 10 \mathrm{mM}$ EDTA, and 0.1\% Tween-20, pH 7.5 with $\mathrm{HCl}$ ) followed by sonication for $30 \mathrm{sec}$ at $4^{\circ} \mathrm{C}$. Twenty microliters of the cellular lysate was mixed with $3 \mathrm{~mL}$ of the enzyme solution supplied and incubated for $10 \mathrm{~min}$ at $37^{\circ} \mathrm{C}$. The absorbance at $550 \mathrm{~nm}$ was measured within $60 \mathrm{~min}$. For internal control, the DNA concentration in 3T3-L1 cells was determined by spectrophotometry and DNA concentration in $\mu \mathrm{g} / \mu \mathrm{g}$ was calculated.

2.7. Oil Red O Staining. The 3T3-L1 adipocytes were carefully washed twice with PBS and then fixed and dried with $10 \%$ formalin for $20 \mathrm{~min}$. After removal of the formalin, $60 \%$ isopropanol was added to each well for $3 \mathrm{~min}$ and cells were washed thoroughly with PBS to remove unbound dye. Cells were then incubated with the Oil red $\mathrm{O}$ solution for $20 \mathrm{~min}$ and washed three times with distilled water. The staining of lipid droplets and cell morphology was ascertained microscopically and quantified by the i-solution program (IMT i-Solution, Seoul, Korea) using an Axiocam MRc5 CCD camera (Carl Zeiss, Jena, Germany) at $\times 200$ magnification.

2.8. Gene Expression. Total cellular RNA was extracted from 3T3-L1 adipocytes using Trizol reagent and centrifuged at $12,000 \mathrm{rpm}$ for $10 \mathrm{~min}$ at $4^{\circ} \mathrm{C}$. One microgram of total RNA was reverse transcribed to CDNA for $60 \mathrm{~min}$ at $42^{\circ} \mathrm{C}$ and then $15 \mathrm{~min}$ at $72^{\circ} \mathrm{C}$, using an RT-PCR system (TaKaRa Biotechnology, Seoul, Korea) that contained reverse transcriptase buffer, oligo (dT) 12-mer, $10 \mathrm{mM}$ dNTP, $0.1 \mathrm{M}$ dithiothreitol, reverse transcriptase, and RNase inhibitor. PCR using primers specific for each cDNA was carried out in a $20 \mu \mathrm{L}$ PCR reaction mixture supplied by TaKaRa supplemented with 2.5 units of TaKaRa Taq, $1.5 \mathrm{mM}$ of each dNTP, 1x PCR buffer, and $20 \mathrm{pmol}$ of each primer. The primer sequences of HSL, LPL, and $\beta$-actin used for gene expression analysis are shown in Table 1 . The reaction was denatured at $95^{\circ} \mathrm{C}$ for $1 \mathrm{~min}$, annealed at $55^{\circ} \mathrm{C}$ for $1 \mathrm{~min}$, and extended at $72^{\circ} \mathrm{C}$ for $30 \mathrm{sec}$. Amplification for HSL or LPL was carried out using 30 cycles, and final extension was performed at $72^{\circ} \mathrm{C}$ for $7 \mathrm{~min}$. An equal volume of each PCR was analyzed by $1.5 \%$ agarose gel electrophoresis and ethidium bromide staining. Signal intensity was quantified with the Gel Doc EQ (BIO-RAD Laboratories, Hercules, CA, USA). Marker gene expression was normalized to $\beta$-actin expression in each sample.

2.9. Western Blot Analysis. Following incubation, 3T3-L1 adipocytes were lysed with a ice-cold lysis buffer. Total proteins $(20 \mu \mathrm{g})$ were separated by $4 \%-12 \%$ SDS-PAGE under reducing conditions, and the separated proteins were transferred to Hybond-C nitrocellulose membranes (Amersham Biosciences, Piscataway, NJ, USA) at $300 \mathrm{~mA}$ for $90 \mathrm{~min}$. After blocking with 5\% nonfat skim milk for $2 \mathrm{hr}$, each membrane was probed with a 1:1,000 dilution of the particular primary antibody (mouse monoclonal antibody to $\operatorname{PPAR} \gamma, \mathrm{C} / \mathrm{EBP} \alpha, \mathrm{SREBP}-1$, or $\beta$-actin) for $12 \mathrm{hr}$. The membrane was washed with Tris-buffered saline-Tween solution (140 $\mathrm{mM} \mathrm{NaCl}_{2}, 10 \mathrm{mM}$ Tris- $\mathrm{HCl}, \mathrm{pH}$ 8.0, and 0.05\% Triton $\mathrm{X}-100$ ) and incubated with a HRP-conjugated anti-mouse IgG antibody. Immunoreactive protein expression was visualized by an enhanced chemiluminescence (Amersham, Arlington Heights, IL, USA) and signal was detected using an Image Station 4000R (Kodak, New Haven, CT, USA). Anti- $\beta$ actinantibody was used to verify that equal amounts of proteins were loaded in all lanes.

2.10. Statistical Analysis. The values are expressed as the mean \pm standard error of the mean (SEM). The data were analyzed by $t$-test or one-way analysis of variance (ANOVA) followed by Scheffe's multiple comparison test or Tukey's multiple comparison test for statistically significant differences between groups using the SAS statistical package (SAS Institute, Cary, NC, USA). Statistical significance was assessed at a level of $P<0.05$.

\section{Results}

3.1. Effect of Gambisan and Its Major Component Extracts on Cell Viability in 3T3-L1 Cells. To examine the intracellular toxicity, 3T3-L1 cells were treated with a range of concentrations $(0,0.01,0.1,1,10,100$, and $1,000 \mu \mathrm{g} / \mathrm{mL})$ of Gambisan and its major component extracts for $72 \mathrm{hr}$ and 10 days, and the cell viability was determined using the MTT assay and LDH assay, respectively. Viability of 3T3-L1 cell populations treated with Ephedra intermedia Schrenk, Atractylodes lancea DC., and Thea sinensis L. for $72 \mathrm{hr}$ was markedly decreased to the extent that the survival rates of 
cells were only about $60 \%$ even at the initial concentration of $0.01 \mu \mathrm{g} / \mathrm{mL}$ (Figures 2(a)(B), 2(a)(C), and 2(a)(D)). However, Gambisan did not show a significant effect on 3T3-L1 cell viability at concentrations up to $100 \mu \mathrm{g} / \mathrm{mL}$, and the extent of inhibition did not exceed $\mathrm{IC}_{50}$ in all concentrations of Gambisan (Figures 2(a)(A) and 2(b)(A)). To focus specifically on the noncytotoxic range of Gambisan, concentrations of $0-500 \mu \mathrm{g} / \mathrm{mL}$ were used in the following experiments. In addition, the viability in 3T3-L1 cells treated with Gambisan for $72 \mathrm{hr}$ was significantly higher than that of populations treated with the major component extracts at every concentration $(P<0.0001$, ANOVA with Scheffe's test), and the viability in Gambisan-treated 3T3-L1 cells for 10 days was also significantly higher than that of populations treated with the major component extracts at concentrations of $1,10,100$ and $1,000 \mu \mathrm{g} / \mathrm{mL}(P<0.05$, ANOVA with Tukey's test $)$.

\subsection{Effect of Gambisan and Its Major Component Extracts on} TG Deposition and DNA Contents of 3T3-L1 Cells. To evaluate the effect of Gambisan and its major component extracts on TG deposition and DNA contents of differentiating 3T3-L1 cells, 3T3-L1 cells were treated with various doses $(0,100$, 250 , and $500 \mu \mathrm{g} / \mathrm{mL}$ ) of Gambisan or its major components. After 10 days, TG and DNA contents in 3T3-L1 cells were determined. TG contents in 3T3-L1 cells treated with Gambisan and its major component extracts were significantly decreased in a dose-dependent manner. In addition, the TG contents in 3T3-L1 cells treated with Gambisan were significantly higher compared with its major component extracts at the concentrations of 150 and $500 \mu \mathrm{g} / \mathrm{mL}(P<0.0001$, ANOVA with Scheffe's test) (Figure 3(a)). However, the DNA contents of 3T3-L1 cells treated with all concentrations (0, 100,250 , and $500 \mu \mathrm{g} / \mathrm{mL}$ ) of Gambisan were not significantly decreased, but the DNA contents of 3T3-L1 cells treated with its major component extracts were all significantly decreased in a concentration-dependent manner. The DNA contents of 3T3-L1 cells treated with Gambisan were significantly higher than its major component extracts at all concentrations $(P<$ 0.0001, ANOVA with Scheffe's test).

\subsection{Effect of Gambisan on Lipid Accumulation in 3T3-L1 Cells.} To determine the effect of Gambisan on lipid accumulation in 3T3-L1 cells, 3T3-L1 cells were treated with various doses $(0,100,250$, and $500 \mu \mathrm{g} / \mathrm{mL})$ of Gambisan. After 10 days, intracellular lipid accumulation was examined with Oil red O staining for lipid droplets as an indicator of the degree of adipogenesis. As shown in Figure 4(c), copious Oil red $\mathrm{O}$ dye stained material accumulated in most of untreated control 3T3-L1 cells as evidence of adipogenesis. Microscopic images of treated 3T3-L1 cells captured after Oil red $\mathrm{O}$ staining revealed that the number of detectable stained droplets decreased as the concentration of Gambisan increased. In addition, the lipid accumulation rate was significantly reduced with all concentrations of Gambisan treatment compared with the control; the decrease was dose dependent $(P<0.001)$; accumulation was about $54.7 \%$,
$45.6 \%$, and $40.0 \%$ at a Gambisan concentration of $100 \mu \mathrm{g} / \mathrm{mL}$, $250 \mu \mathrm{g} / \mathrm{mL}$, and $500 \mu \mathrm{g} / \mathrm{mL}$, respectively (Figure $4(\mathrm{~b})$ ).

3.4. Effect of Gambisan on Adipocyte-Specific Gene and Major Adipogenic Transcriptional Factor Expression in 3T3-L1 Cells. To quantify the effect of Gambisan on adipocyte-specific gene and major adipogenic transcriptional factor expression in 3T3-L1 cells during adipogenesis, 3T3-L1 cells were treated with various doses $(0,10,100,250$, and $500 \mu \mathrm{g} / \mathrm{mL})$ of Gambisan. After 10 days, RT-PCR and Western blot analysis were conducted. As shown in Figures 5(a) and 5(c), Gambisan reduced the mRNA expression of adipocyte-specific genes for HSL and LPL and the protein levels of major adipogenic transcriptional factors, such as PPAR $\gamma, \mathrm{C} / \mathrm{EBP} \alpha$, and SREBP1, in 3T3-L1 cells in a dose-dependent manner. In particular, all these expression levels were significantly reduced except HSL, LPL, C/EBP $\alpha$, and SREBP-1 at the initial concentration of $10 \mu \mathrm{g} / \mathrm{mL}$ of Gambisan compared with control (Figures $5(b)$ and $5(c))$. These results were specific because $\beta$-actin levels were not affected.

\section{Discussion}

In vitro models have been meaningful in verifying the mechanisms related to the adipocyte differentiation, adipogenesis, and gene expression. Among others, 3T3-L1 preadipocytes, which can be induced to differentiate into adipocytes according to the coordinated program, are one of the most useful and established cell lines for researching the adipogenesis process $[26,27]$. In 3T3-L1 cells, in vivo adipocyte development and lipid accumulation induction can be reliably reproduced equivalent to human preadipocytes [28]. For this reason, we naturally adopted these cells at the beginning of this research to identity the feasibility of Gambisan as a possible new anti-obesity herbal agent.

The cell viability results of the present study imply that the decrease of TG deposition and lipid accumulation in 3T3-L1 cells treated with Gambisan, apart from its major component (Ephedra intermedia Schrenk, Atractylodes lancea DC., and Thea sinensis $\mathrm{L}$.) extracts, was not due to its cytotoxicity, but to its own antiadipogenic properties. Meanwhile, it is true that herbal drugs are mostly prescribed as a compound formula of multiple medicinal herbs rather than a single herb, based on the combination principles of traditional Korean medicine [29]. Actually, the synergistic effects of mixed formula, usually termed as mutual reinforcement, may be induced by the interaction among herbs, and the adverse effects of any single component may be neutralized by another, a concept termed mutual suppression. So, we designed and conducted a cytotoxicity comparison experiment comparing Gambisan alone with its major component extracts. However, this issue still remains unsolved despite the interesting results that the cell viability and DNA contents in 3T3-L1 cells treated with Gambisan were significantly higher than its major component extracts at every concentration.

The complex process of adipogenesis starts by the production of $\operatorname{PPAR} \gamma$, which is controlled and activated by 


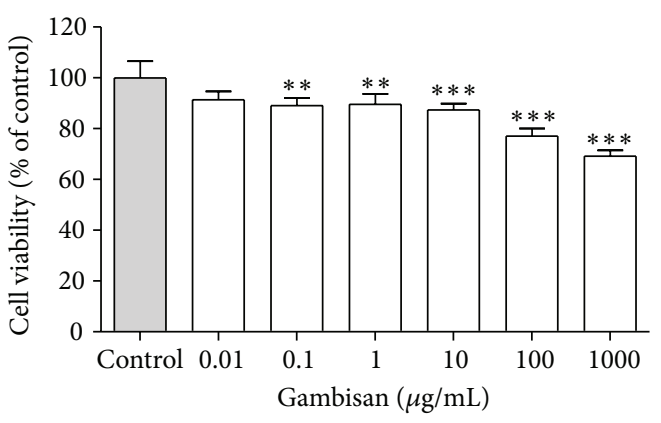

(A)

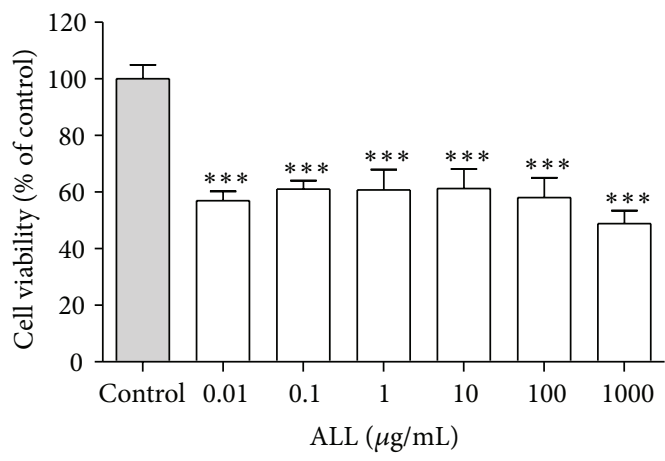

(C)

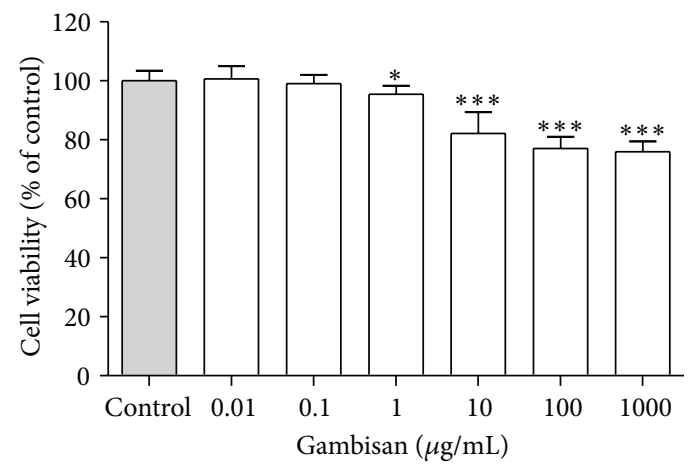

(A)

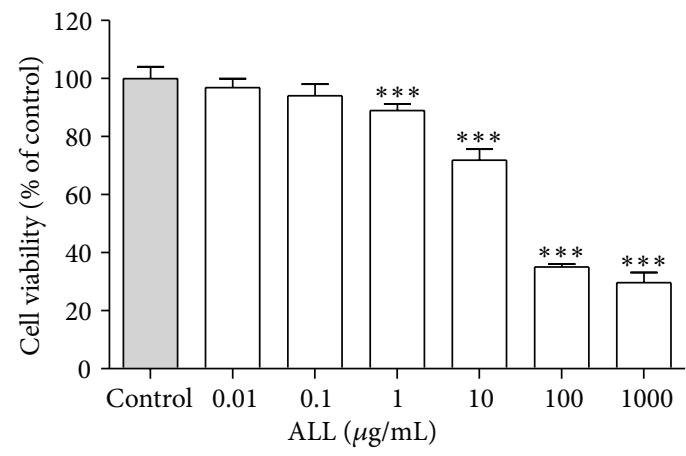

(C)

(a)

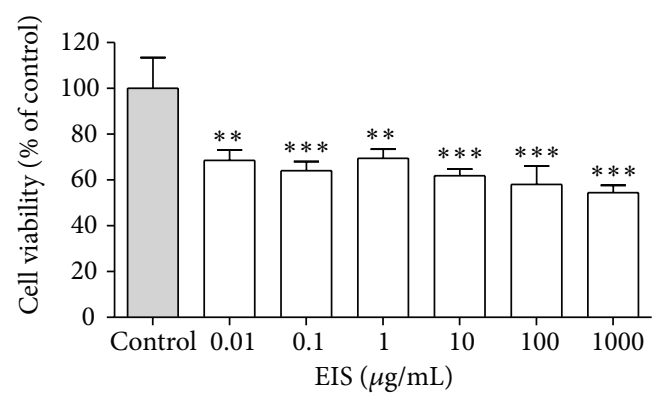

(B)

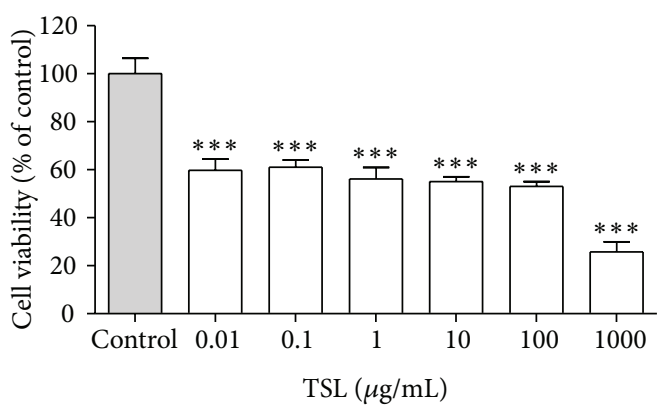

(D)

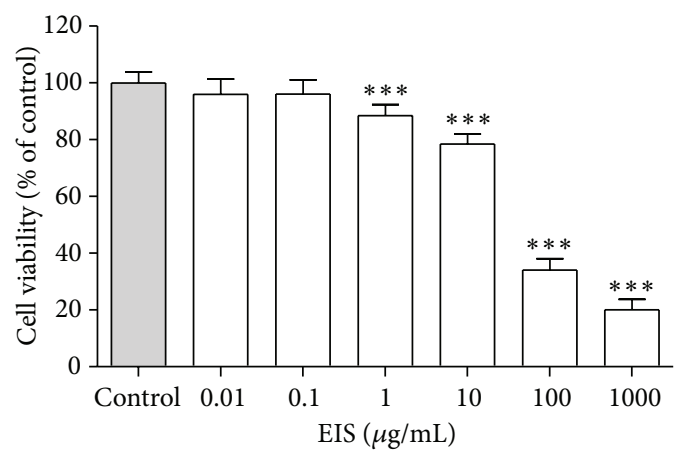

(B)

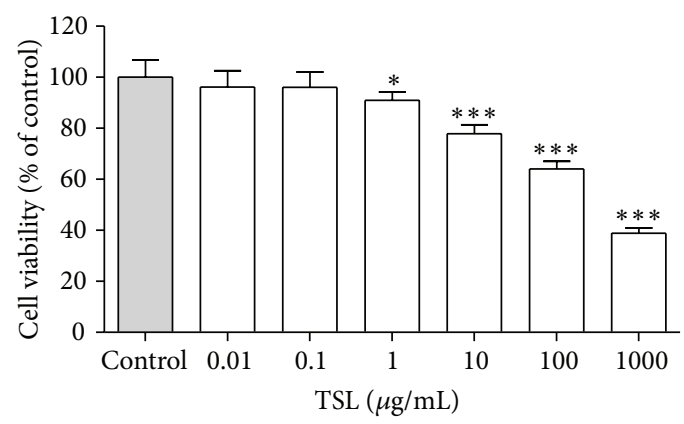

(D)

(b)

FIGURE 2: Effect of Gambisan and its major component extracts on 3T3-L1 cell viability. 3T3-L1 cells were treated with various doses (0.01$1000 \mu \mathrm{g} / \mathrm{mL}$ ) of Gambisan (A) or its major components (Ephedra intermedia Schrenk (B), Atractylodes lancea DC. (C) and Thea sinensis L. (D)). Cell viability was measured by the MTT assay after $72 \mathrm{hr}$ (a) and by the LDH assay after 10 days (b). The percentage of viable cells was calculated by defining the cell viability without treatment as $100 \%$. Values are expressed as mean \pm SEM of six independent experiments. ${ }^{* *} P<0.01,{ }^{* * *} P<0.001$ compared with control (expressed by $t$-test). EIS: Ephedra intermedia Schrenk, ALL: Atractylodes lancea DC., TSL:

Thea sinensis L., MTT assay: methyl thiazol tetrazolium assay, LDH assay: lactate dehydrogenase assay. 


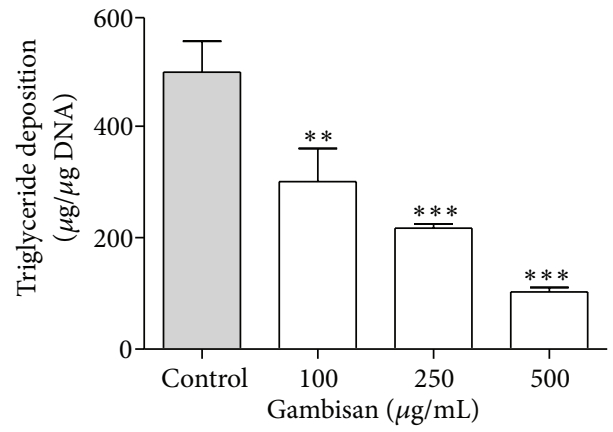

(A)

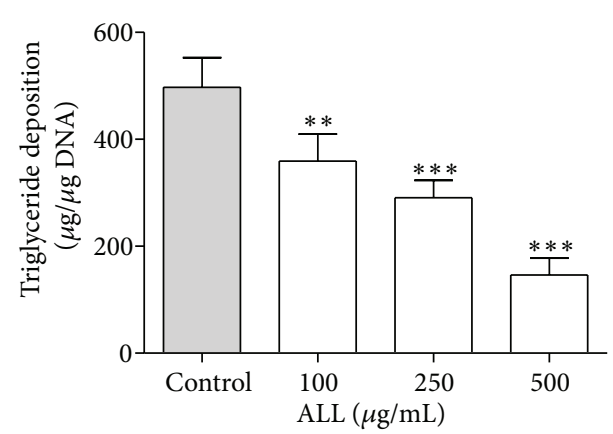

(C)

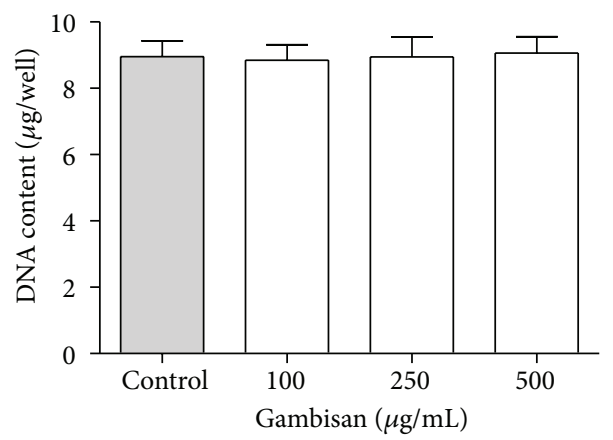

(A)

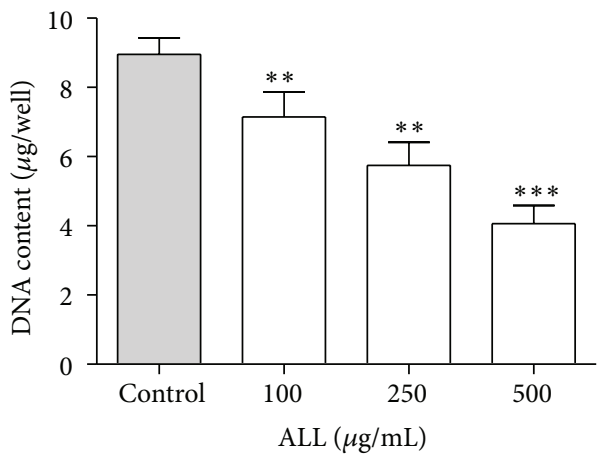

(C)

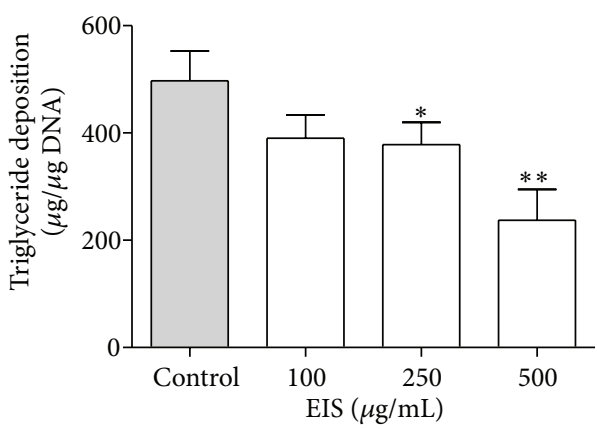

(B)

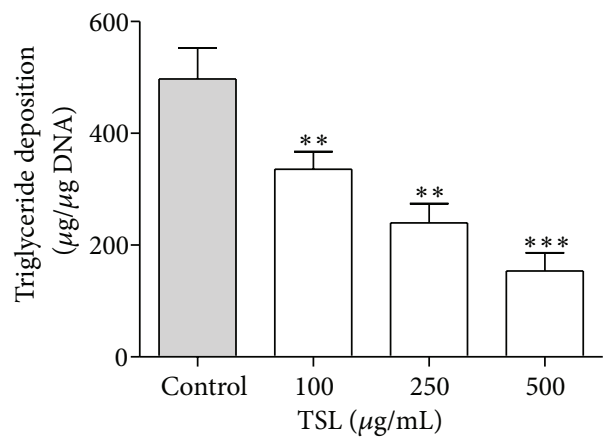

(D)

(a)

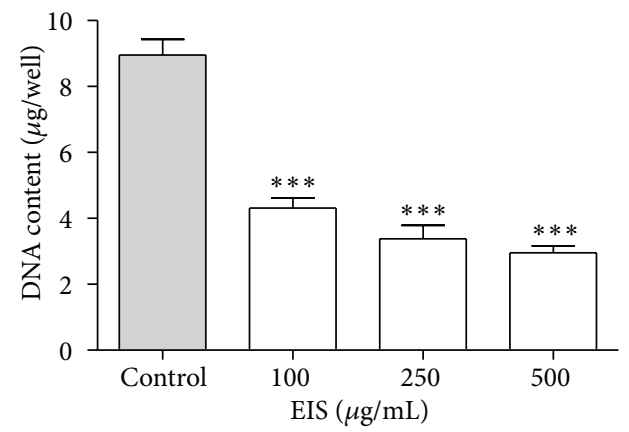

(B)

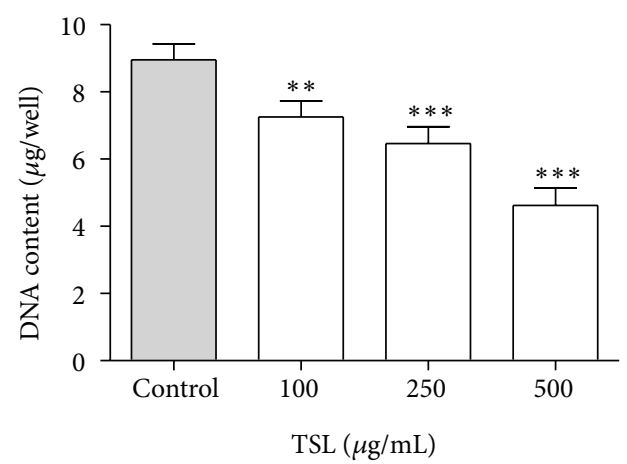

(D)

(b)

FIGURE 3: Effect of Gambisan and its major component extracts on the TG deposition and DNA contents in 3T3-L1 cells. 3T3-L1 cells were treated with various doses $(0,100,250$, and $500 \mu \mathrm{g} / \mathrm{mL}$ ) of Gambisan or its major components (Ephedra intermedia Schrenk, Atractylodes lancea DC., and Thea sinensis L.). After 10 days, the cellular TG contents (a) were measured with TG determination kit at $550 \mathrm{~nm}$. The DNA contents in 3T3-L1 cells (b) were measured as internal control. Values are expressed as mean \pm SEM of five independent experiments. ${ }^{*} P<0.05,{ }^{* *} P<0.01,{ }^{* * *} P<0.001$ compared with control (expressed by $t$-test). EIS: Ephedra intermedia Schrenk, ALL: Atractylodes lancea DC., TSL: Thea sinensis L. 


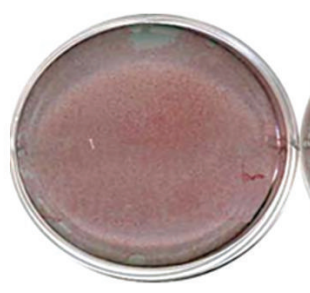

Control

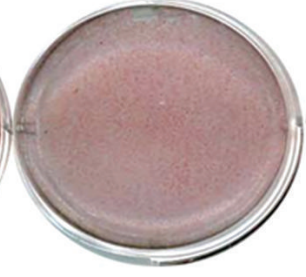

Gambisan $100(\mu \mathrm{g} / \mathrm{mL})$

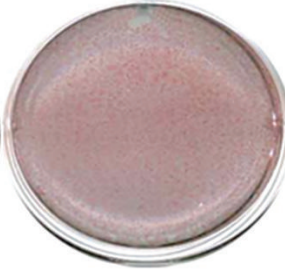

Gambisan $250(\mu \mathrm{g} / \mathrm{mL})$

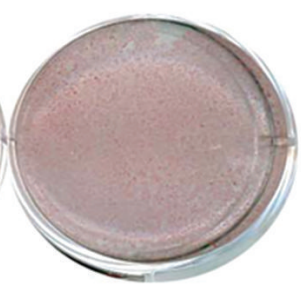

Gambisan $500(\mu \mathrm{g} / \mathrm{mL})$

(a)

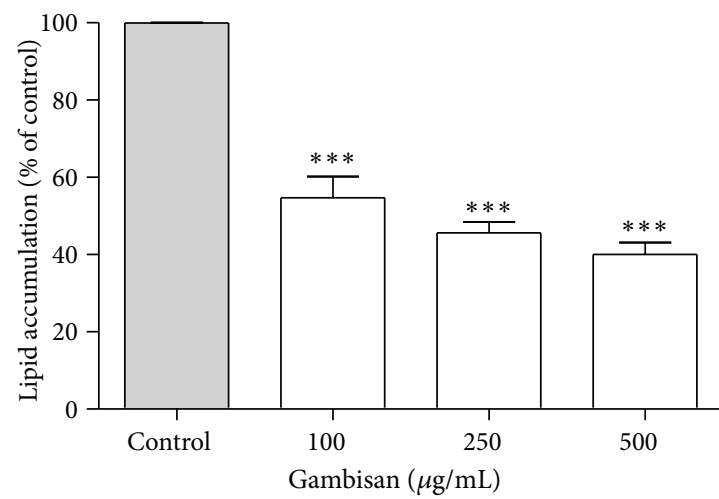

(b)

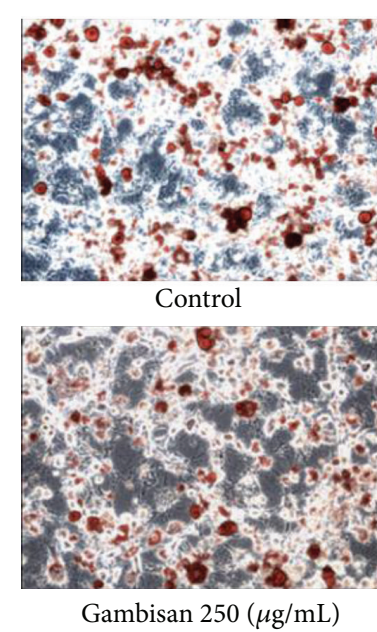

(c)

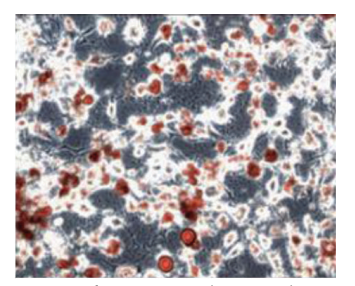

Gambisan $100(\mu \mathrm{g} / \mathrm{mL})$

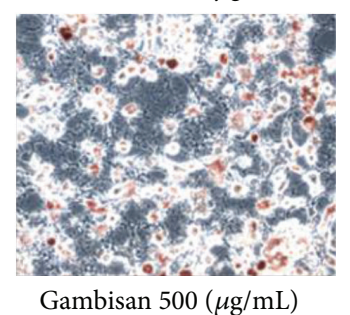

FIGURE 4: Effect of Gambisan on lipid accumulation in 3T3-L1 cells. 3T3-L1 cells were treated with various doses $(0,100,250$, and 500 $\mu \mathrm{g} / \mathrm{mL})$ of Gambisan. After 10 days, cells were fixed and stained with Oil red O dye. Images of representative cells (a) scanned, (c) captured with a microscope (200x magnification), and (b) quantified by the i-solution program using a CCD camera are shown. The extent of lipid accumulation was expressed as the percentage of control. Values are expressed as mean \pm SEM of five independent experiments. ${ }^{* * *} P<0.001$ compared with control (expressed by $t$-test).

$\mathrm{C} / \mathrm{EBP} \alpha$ and SREBP-1. Among them, PPAR $\gamma$ plays a role of a key transcription factor triggering and upregulating the subsequent expression of adipocyte-specific genes like adipocyte-fatty acid binding proteins (A-FABP) responsible for TG accumulation during adipocyte differentiation [30, 31]. $\mathrm{C} / \mathrm{EBP} \alpha$, which is expressed rather late in the adipogenesis process, appears to promote differentiation in cooperation with PPAR $\gamma$ by cross regulation [32]. SREBP-1 regulates lipogenic gene expression associated with fatty acid synthesis, which leads to increased synthesis of TG, and can contribute to the expression of PPAR $\gamma$ ligands [33]. These adipogenic transcription factors act as master regulators of adipogenesis and lipid storage in 3T3-L1 cells. Because their overexpression can critically accelerate the differentiation of adipocytes, they may serve as potential therapeutic targets for obesity treatment and prevention. Considering the mechanism and western blot analysis results of these adipogenic transcription factors, they appear to be consistent with decrease in TG and lipid accumulation.

HSL, which hydrolyzes triacylglycerol to monoacylglycerol and free fatty acids, is considered as one of the key lipolytic response genes related to lipid catabolism in adipocytes
[34]. On the other hand, LPL is an early marker of adipocyte differentiation that dissolves lipid in lipoproteins into two free fatty acids and one monoacylglycerol to allow fatty acid entry into fat tissue, so LPL overexpression can indicate the initiation of lipid accumulation $[35,36]$. In this study, the expression of both HSL and LPL was significantly inhibited by Gambisan treatment in a dose-dependent manner. In this sense, the anti-obesity effects of Gambisan appear to be exerted, not by the lipolysis pathway related with HSL, but by the dose-dependent downregulation of LPL.

In conclusion, our results demonstrate that Gambisan efficiently inhibits adipogenesis in 3T3-L1 adipocytes as indicated by significant reduction in intracellular TG contents and lipid accumulation in a dose-dependent manner without eliciting apparent cytotoxicity. Furthermore, these suppressive effects of Gambisan are possibly mediated by down-regulated expressions of LPL mRNA and major adipogenic transcription activator $(\operatorname{PPAR} \gamma, \mathrm{C} / \mathrm{EBP} \alpha$, and SREBP-1) proteins of the adipogenesis pathway and via an HSL-independent pathway.

Therefore, Gambisan may provide a possible therapeutic approach for the prevention and treatment of obesity. Further 


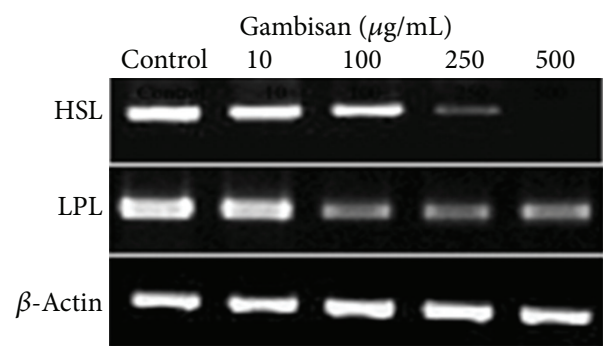

(a)
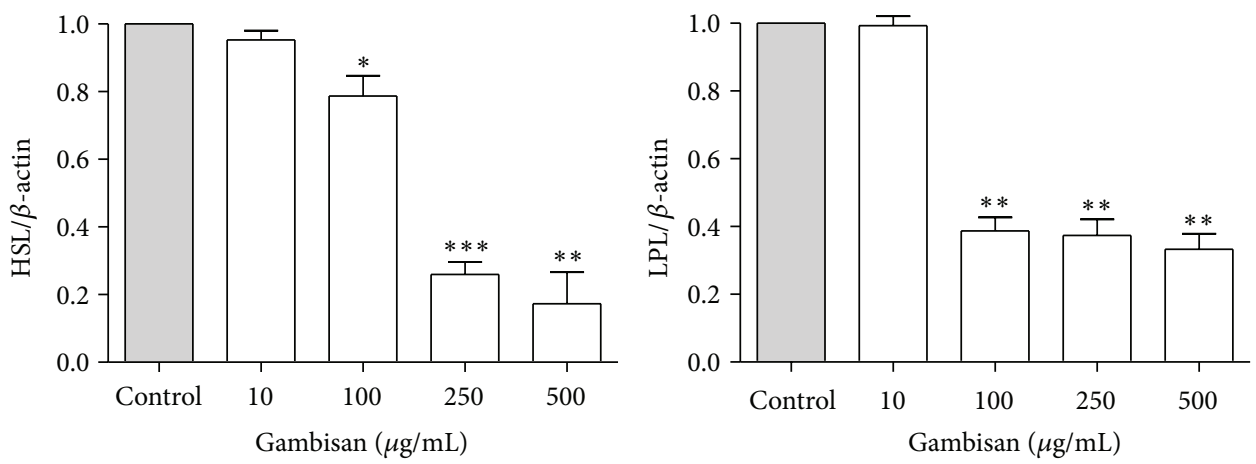

(b)

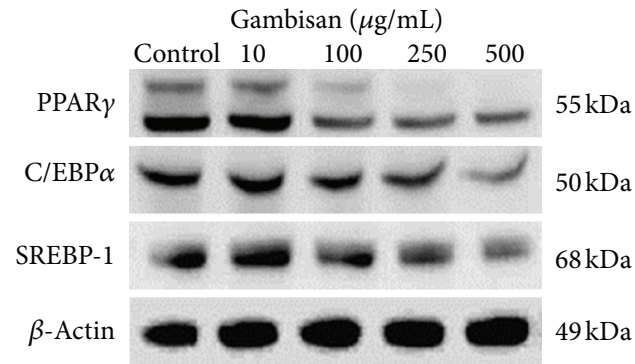

(c)
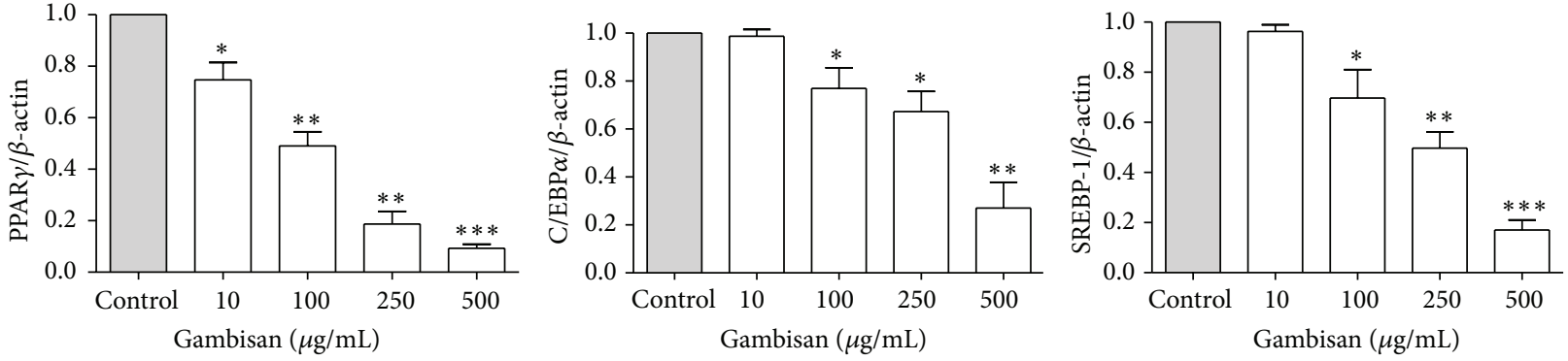

(d)

FIGURE 5: Effect of Gambisan on adipocyte-specific gene and major adipogenic transcriptional factor expression in 3T3-L1 cells. 3T3-L1 cells were treated with various doses $(0,10,100,250$, and $500 \mu \mathrm{g} / \mathrm{mL})$ of Gambisan. After 10 days, the mRNA expression levels of HSL and LPL were measured using RT-PCR, and the protein expression levels of PPAR $\gamma, \mathrm{C} / \mathrm{EBP} \alpha$, and SREBP-1 were measured using western blot analysis. Insets show representative RT-PCR band (a) and western blot analysis band (c) used for quantification, and bar graphs represent the band intensities of PCR products (b) and of western blots (d) adjusted by $\beta$-actin used as the internal control. Values are expressed as mean \pm SEM of three independent experiments. ${ }^{*} P<0.05,{ }^{* *} P<0.01,{ }^{* * *} P<0.001$ compared with control (expressed by $t$-test). HSL: hormone-sensitive lipase, LPL: lipoprotein lipase, RT-PCR: reverse transcription-polymerase chain reaction, PPAR $\gamma$ : peroxisome proliferator-activated receptor gamma, C/EBP $\alpha$ : CCAAT/enhancer binding protein alpha, SREBP-1: sterol regulatory element binding protein-1. 
in vivo research and clinical trials are still needed to clarify the efficacy, safety, and precise molecular mechanisms of the anti-obesity effects of Gambisan.

\section{Conflict of Interests}

The authors have declared that they have no conflict of interests.

\section{Authors' Contribution}

The two corresponding authors (Jae-Dong Lee and JeongEun Huh) contributed equally to this paper.

\section{Acknowledgment}

This study was funded by the program of the Kyung Hee University for the young medical researcher in 2010 (KHU20100755).

\section{References}

[1] P. G. Kopelman, "Obesity as a medical problem," Nature, vol. 404, no. 6778, pp. 635-643, 2000.

[2] S. Z. Yanovski and J. A. Yanovski, "Obesity," New England Journal of Medicine, vol. 346, no. 8, pp. 591-602, 2002.

[3] Y. Hong, M. Kim, and M. Yoon, "The anti-angiogenic herbal extracts Ob-X from Morus alba, Melissa officinalis, and Artemisia capillaris suppresses adipogenesis in 3T3-L1 adipocytes," Pharmaceutical Biology, vol. 49, no. 8, pp. 775-783, 2011.

[4] G. Frühbeck, J. Gómez-Ambrosi, F. J. Muruzábal, and M. A. Burrell, "The adipocyte: a model for integration of endocrine and metabolic signaling in energy metabolism regulation," American Journal of Physiology-Endocrinology and Metabolism, vol. 280, no. 6, pp. E827-E847, 2001.

[5] J. Lin, M. A. Della-Fera, and C. A. Baile, "Green tea polyphenol epigallocatechin gallate inhibits adipogenesis and induces apoptosis in 3T3-L1 adipocytes," Obesity Research, vol. 13, no. 6, pp. 982-990, 2005.

[6] M. K. Huntington and R. A. Shewmake, "Behavioral and medical management of obesity," South Dakota Medicine, pp. 51-55, 2011.

[7] L. E. Burke and J. Wang, "Treatment strategies for overweight and obesity," Journal of Nursing Scholarship, vol. 43, no. 4, pp. 368-375, 2011.

[8] D. Cooke and S. Bloom, "The obesity pipeline: current strategies in the development of anti-obesity drugs," Nature Reviews Drug Discovery, vol. 5, no. 11, pp. 919-931, 2006.

[9] G. Derosa and P. Maffioli, "Anti-obesity drugs: a review about their effects and their safety," Expert Opinion on Drug Safety, vol. 11, no. 3, pp. 459-471, 2012.

[10] C. K. Kim, M. Kim, S. D. Oh et al., "Effects of Atractylodes macrocephala Koidzumi rhizome on 3T3-L1 adipogenesis and an animal model of obesity," Journal of Ethnopharmacology, vol. 137, no. 1, pp. 396-402, 2011.

[11] Y. Wang, M. Deng, S. Zhang, Z. Zhou, and W. Tian, "Parasitic loranthus from Loranthaceae rather than Viscaceae potently inhibits fatty acid synthase and reduces body weight in mice," Journal of Ethnopharmacology, vol. 118, no. 3, pp. 473-478, 2008.
[12] A. J. Guo, R. C. Choi, A. W. Cheung et al., "Stimulation of Apolipoprotein A-IV expression in Caco-2/TC7 enterocytes and reduction of triglyceride formation in 3T3-L1 adipocytes by potential anti-obesity Chinese herbal medicines," Chinese Medicine, vol. 4, p. 5, 2009.

[13] S. Jeong, K. Chae, Y. S. Jung et al., "The Korean traditional medicine Gyeongshingangjeehwan inhibits obesity through the regulation of leptin and PPAR $\alpha$ action in OLETF rats," Journal of Ethnopharmacology, vol. 119, no. 2, pp. 245-251, 2008.

[14] H. Lee, R. Kang, and Y. Yoon, "SH21B, an anti-obesity herbal composition, inhibits fat accumulation in 3T3-L1 adipocytes and high fat diet-induced obese mice through the modulation of the adipogenesis pathway," Journal of Ethnopharmacology, vol. 127, no. 3, pp. 709-717, 2010.

[15] S. Park, J. B. Lee, and J. W. Daily, "Anti-obesity effects of ChangChul-Eui-Ee-In-Tang [see text] in female rats with diet-induced obesity," Chinese Journal of Integrative Medicine, vol. 17, no. 12, pp. 925-932, 2011.

[16] C. H. Park, S. J. Jeong, H. J. Lee et al., “Traditional medicine Taeeumjowitangkagambang exerts antiobesity and hypolipidemic effects via antioxidant enzyme enhancement," Phytotherapy Research, vol. 24, no. 11, pp. 1700-1709, 2010.

[17] G. C. Schmitt, M. D. Arbo, A. L. Lorensi et al., "Toxicological effects of a mixture used in weight loss products: $\mathrm{p}$-synephrine associated with ephedrine, salicin, and caffeine," International Journal of Toxicology, vol. 31, no. 2, pp. 184-191, 2012.

[18] H. Nakabayashi, T. Hashimoto, H. Ashida, S. Nishiumi, and K. Kanazawa, "Inhibitory effects of caffeine and its metabolites on intracellular lipid accumulation in murine 3T3-L1 adipocytes," BioFactors, vol. 34, no. 4, pp. 293-302, 2008.

[19] S. Hasani-Ranjbar, N. Nayebi, B. Larijani, and M. Abdollahi, "A systematic review of the efficacy and safety of herbal medicines used in the treatment of obesity," World Journal of Gastroenterology, vol. 15, no. 25, pp. 3073-3085, 2009.

[20] S. V. Joyal, "A perspective on the current strategies for the treatment of obesity," Current Drug Targets, vol. 3, no. 5, pp. 341356, 2004.

[21] H. S. Moon, C. S. Chung, H. G. Lee, T. G. Kim, Y. J. Choi, and C. S. Cho, "Inhibitory effect of (-)-epigallocatechin-3-gallate on lipid accumulation of 3T3-L1 cells," Obesity, vol. 15, no. 11, pp. 2571-2582, 2007.

[22] J. K. Dunnick, G. Kissling, D. K. Gerken, M. A. Vallant, and A. Nyska, "Cardiotoxicity of Ma Huang/caffeine or ephedrine/caffeine in a rodent model system," Toxicologic pathology, vol. 35, no. 5, pp. 657-664, 2007.

[23] L. D. Roberts, S. Virtue, A. Vidal-Puig, A. W. Nicholls, and J. L. Griffin, "Metabolic phenotyping of a model of adipocyte differentiation," Physiological Genomics, vol. 39, no. 2, pp. 109119, 2009.

[24] S. Dave, N. J. Kaur, R. Nanduri, H. K. Dkhar, A. Kumar, and P. Gupta, "Inhibition of adipogenesis and induction of apoptosis and lipolysis by stem bromelain in 3T3-L1 adipocytes," PLoS ONE, vol. 7, no. 1, Article ID e30831, 2012.

[25] U. A. White and J. M. Stephens, "Transcriptional factors that promote formation of white adipose tissue," Molecular and Cellular Endocrinology, vol. 318, no. 1-2, pp. 10-14, 2010.

[26] O. A. MacDougald and S. Mandrup, "Adipogenesis: forces that tip the scales," Trends in Endocrinology and Metabolism, vol. 13, no. 1, pp. 5-11, 2002.

[27] S. P. Poulos, M. V. Dodson, and G. J. Hausman, "Cell line models for differentiation: preadipocytes and adipocytes," Experimental Biology and Medicine, vol. 235, no. 10, pp. 1185-1193, 2010. 
[28] D. C. Lagace and M. W. Nachtigal, "Inhibition of histone deacetylase activity by valproic acid blocks adipogenesis," Journal of Biological Chemistry, vol. 279, no. 18, pp. 18851-18860, 2004.

[29] J. H. Park, M. J. Lee, M. Y. Song, S. Bose, B. C. Shin, and H. J. Kim, "Efficacy and safety of mixed oriental herbal medicines for treating human obesity: a systematic review of randomized clinical trials," Journal of Medicinal Food, vol. 15, no. 7, pp. 589597, 2012.

[30] T. Jeon, S. G. Hwang, S. Hirai et al., "Red yeast rice extracts suppress adipogenesis by down-regulating adipogenic transcription factors and gene expression in 3T3-L1 cells," Life Sciences, vol. 75, no. 26, pp. 3195-3203, 2004.

[31] E. D. Rosen and B. M. Spiegelman, "Molecular regulation of adipogenesis," Annual Review of Cell and Developmental Biology, vol. 16, pp. 145-171, 2000.

[32] J. B. Kim and B. M. Spiegelman, "ADD1/SREBP1 promotes adipocyte differentiation and gene expression linked to fatty acid metabolism," Genes and Development, vol. 10, no. 9, pp. 1096-1107, 1996.

[33] M. Y. Park, D. W. Seo, J. Y. Lee et al., "Effects of Panicum miliaceum L. extract on adipogenic transcription factors and fatty acid accumulation in 3T3-11 adipocytes," Nutrition Research and Practice, vol. 5, no. 3, pp. 192-197, 2011.

[34] C. Morimoto, K. Kameda, T. Tsujita, and H. Okuda, "Relationships between lipolysis induced by various lipolytic agents and hormone-sensitive lipase in rat fat cells," Journal of Lipid Research, vol. 42, no. 1, pp. 120-127, 2001.

[35] S. S. Chirala, A. Jayakumar, Z. W. Gu, and S. J. Wakil, "Human fatty acid synthase: role of interdomain in the formation of catalytically active synthase dimer," Proceedings of the National Academy of Sciences of the United States of America, vol. 98, no. 6, pp. 3104-3108, 2001.

[36] A. M. Gonzales and R. A. Orlando, "Role of adipocyte-derived lipoprotein lipase in adipocyte hypertrophy," Nutrition and Metabolism, vol. 4, p. 22, 2007. 


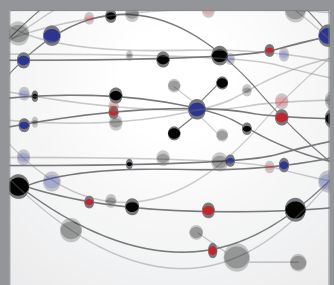

The Scientific World Journal
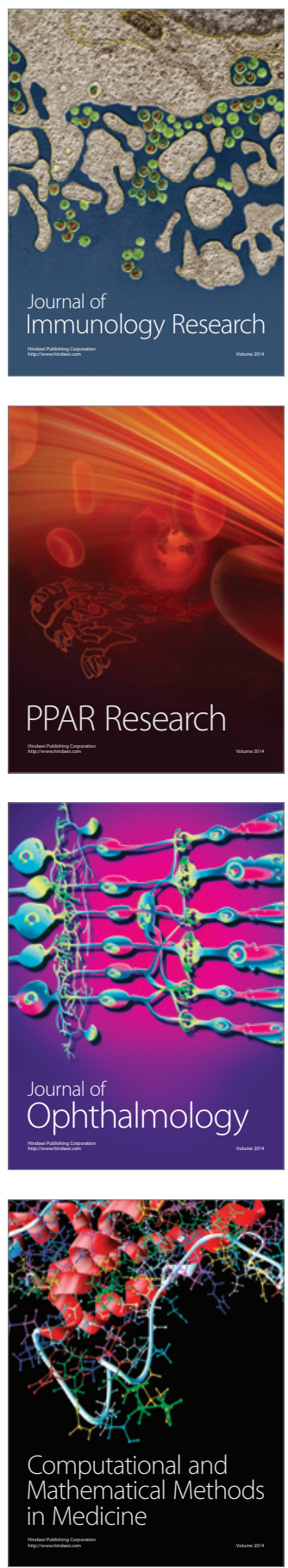

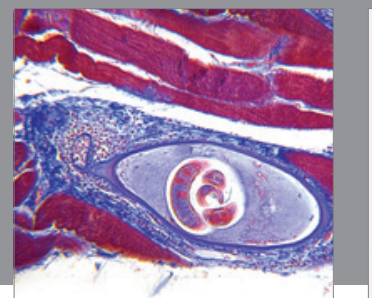

Gastroenterology

Research and Practice
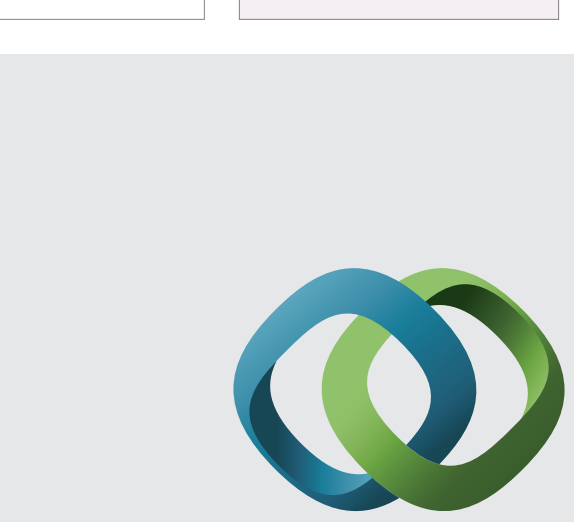

\section{Hindawi}

Submit your manuscripts at

http://www.hindawi.com
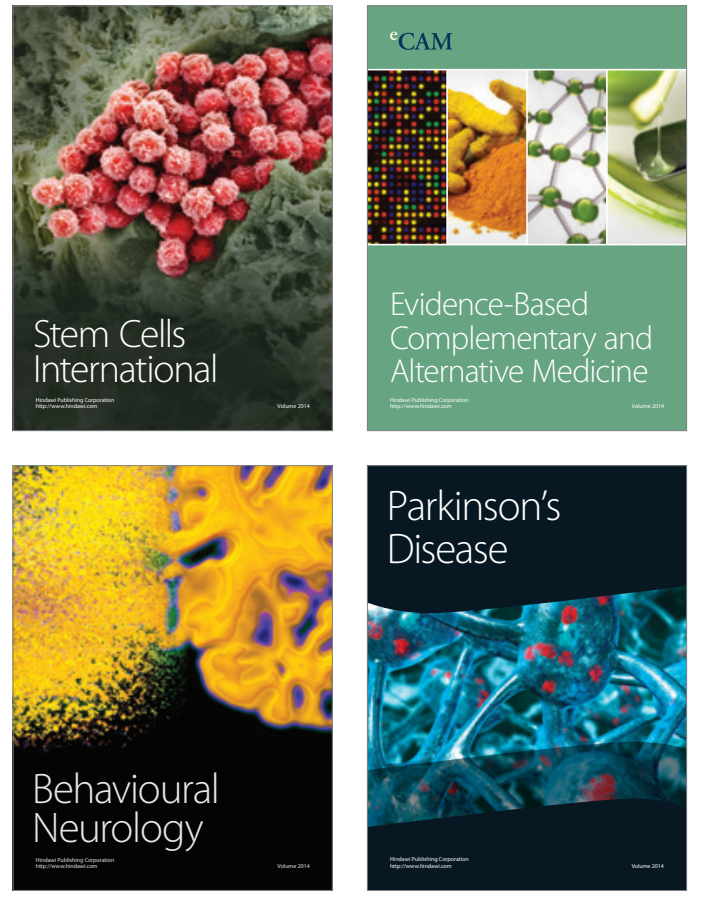
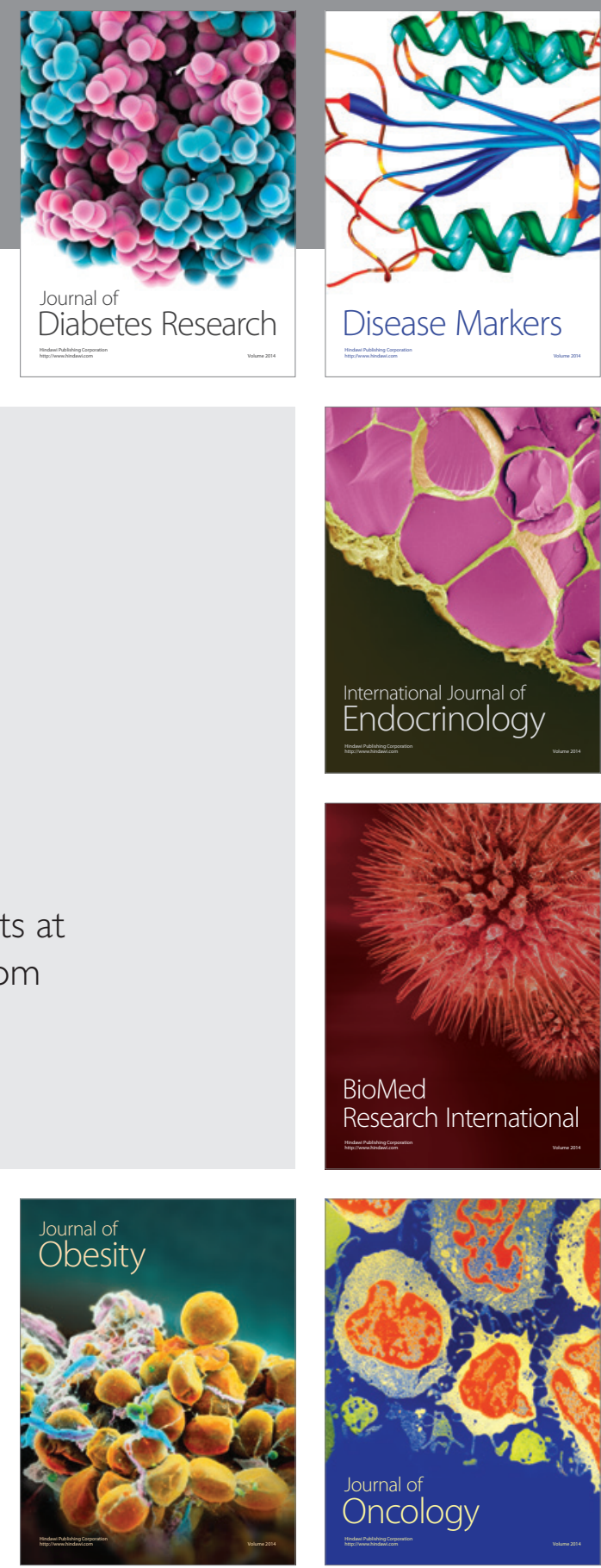

Disease Markers
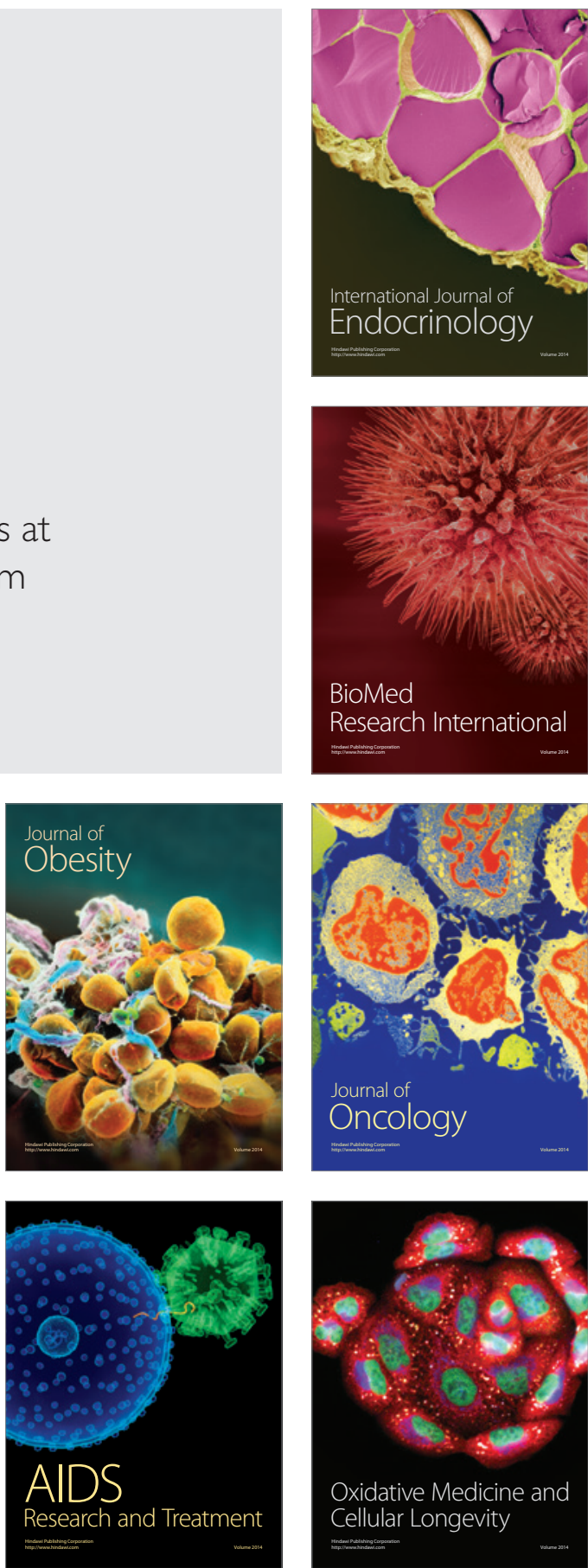